\title{
Contractual Unpredictabiliy in the Context of Covid-19 Pandemic
}

\author{
By Mihaela Elvira Patraus* \& Ionita Maria Ofrim ${ }^{ \pm}$
}

The new realities require a revitalisation of the legal system to overcome the effects of the Covid-19 pandemic. The current health crisis is, at the same time, a challenge not only for public authorities, but also for the scientific community and legal practitioners, concerned with finding viable solutions for the adaptation of legal institutions. For the legal system, the contract is an essential factor from a theoretical and practical point of view, an indispensable element for the sphere of private law; it is an essential piece of evidence that lawyers will support in the face of new challenges posed by the current pandemic context. In this article we have in view an objective analysis of the contractual contingency, starting from the jurisprudential consecration that was conferred under the previous regulation and until the introduction of this institution in the national legislation with the entry into force of the new Romanian Civil Code in 2011. We intend to present a brief retrospective on the theory of unpredictabiliy and will discuss the regulation found in national law, as well as the existence of this institution in comparative law. In a dynamic social and economic context, it is essential to clarify the relationship between the binding force of contracts and the possibility of invoking unpredictabiliy, in situations where certain changes affecting the contractual balance occur in the performance of obligations. At the same time, as a case study, we will try to answer the question whether this institution finds its applicability in the most debated issue at legal, national and international level in the current period, namely the effects on contractual relations, generated by the Covid-19 pandemic and the measures taken by public authorities to limit the effects of the virus on human health. In the sphere of performance of contractual relations, in progress at the time of the pandemic, a multitude of controversies have been created, regarding the possibility of invoking, as the case may be, force majeure, fortuitous event or unpredictabiliy and in this article we will highlight to what extent the parties have these remedies at hand. Last but not least, the study will highlight the jurisprudential orientation due to the significant changes suffered in the current social and economic context amid the Covid-19 pandemic, respectively if the institution of unpredictabiliy comes to help the contracting parties to save the contracts concluded before the pandemic which have been affected in the context of the measures and restrictions taken by each state.

Keywords: Unpredictabiliy; Covid-19 coronavirus pandemic; contractual relations; force majeure; fortuitous event; rebus sic stantibus; pacta sunt servanda.

\footnotetext{
"Associate Professor, Facuty of Law and jurisprudence, School of Law, University of Oradea, Oradea, Romania. E-mail: mihaelapatraus@yahoo.com

${ }^{ \pm} J u d g e$, Zalau Court, Romania. E-mail: ionita.ofrim@gmail.com
} 


\section{Introduction}

In the Romanian civil law, the will of the contracting parties is placed at the center of contractual operations. However, the direct intervention of the legislator and increasingly of the judge in contracts, in the name of public order and in order to reconcile the interests of the contracting parties to ensure contractual balance, is now manifest and necessary in order to meet the requirements of commutative justice. In addition, political and economic change may give rise to new grounds for both the legislator and the judge to call into question those contractual legal relationships directly affected by these external events that cause harm and insecurity to at least one party, if not both.

Unpredictabiliy as a legal institution, is not entirely new in the Romanian civil law, it has its roots in the Romanian legal tradition, where it was shown that conventio omnis intelligitur rebus sic stantibus, an expression that meant that all conventions are considered valid if the circumstances in which have been concluded remain unchanged.

As specific objectives, we formulate the following:

- to analyse from a systemic point of view this mechanism made available to the parties, in order to understand the context in which it appeared, how it developed in the Romanian legal system with the entry into force of the new Civil Code and its express regulation;

- to identify and compare the regulation of this institution in the legislation of France, Germany, England, Italy and Greece, in order to understand the commonalities and differences that exist in the approach of other legislations;

- to present the manner in which the courts have applied this mechanism and how they have intervened in the conventions of the parties in order to safeguard them;

- to point out the most topical discussion, namely the extent to which unpredictabiliy can help the contracting parties affected by the pandemic declared by the World Health Organisation.

\section{Literature Review}

\section{Brief History of the Theory of Unpredictabiliy}

Before moving on to the analysis of contractual unpredictabiliy, as regulated in the new Civil Code, we consider it useful to make a historical foray to see how this institution has been viewed over time, having as a starting point even the Roman law.

From a historical perspective, the theory as such was not enshrined in a general way in the Roman law, but only through a series of interpretative directives, applicable in concrete cases, and the source of the theory of Unpredictabiliy was identified as being in the next passage in Africanus, identified in Solutionibus et 
liberationibus, (Digest, XLVI, 3, fr. 38): „, Tacite enim haec stipulatio videur sit in eadem causam maneat", from which emerges the idea of the existence in the contract of a tacit, implied clauses of termination of the contract, in the event of a change of circumstances ${ }^{1}$.

References that can be associated with the theory of unpredictabiliy can also be found in the works of the jurisconsults Paul, Marcelus or in Justinian's Digest. The relationship between Unpredictabiliy and the obligation of contracts is also found in the works of the Roman philosophers Seneca and Cicero, who conditioned the observance of the promises by maintaining the circumstances as unchanged ${ }^{2}$.

Canon law offered a more evolved perspective on the obligation of the contract, starting from the principles of the laws of equity and charity, thus introducing the idea of commutative justice, operating a non-existent distinction in the Roman law between just and legal: the just is the rule of conduct imposed by a fair conscience, and the legal results from the provisions of public authority.

The most important representative of the canonists, St. Thomas Aquinas is the forerunner of admitting the theory of unpredictabiliy by implying in the contract of a clause, rebus sic stantibus ${ }^{3}$, ("Contractus qui habent tractum succesivum et dependentiam de futuro rebus sic stantibus intelliguntur"). In other words, this implied clause suggests some stability of the conditions taken into account when concluding the contract. The first codification that explicitly recognised the existence in contracts of the rebus sic stantibus clause, with the consequence of the possibility to request partial execution or adaptation of the contract, was the Codex Maximilianeus Bavaricus Civilis enacted in 1756 by the Duke of Bavaria, Maximilian III Joseph, and which was in force until 1900.

In old French law, doctrine and jurisprudence ignored the issue of Unpredictabiliy, as the legislator did not make any mention of the theory of contractual Unpredictabiliy, but only of the principle of autonomy of will. In this regard, the French literature cited, as a classic example, the so-called Craponne Canal Affair, concerning the conclusion of some conventions in 1650 and 1567 on charges for irrigation owed by the owners of an irrigation canal, built by an enterprise, to the latter, on which occasion a sum of 3 saus (or $=$ old French coin worth 5 cents) was fixed, payable periodically. Towards the end of the 19th century, the company operating the canal claimed an increase in the tax, motivating its need due to the decrease in the real value of the currency and the increase in the price of labor. The Court of Cassation of France, by Decision of 6 March 1876, dismissed the action and declared the intangible nature of the contract by virtue of its binding force.

In view of this decision, both the French and Romanian jurisprudence, in accordance with the first, repudiated the idea of redistributing the obligations arising from a contract, in the absence of an agreement of the parties in this regard, for a long time. However, the dynamism of economic and social realities has led to a weakening of this jurisprudential reluctance and the imposition of new

\footnotetext{
${ }^{1} \operatorname{Bradin}(2018)$ at 2.

${ }^{2}$ Zamșa (2006) at 6.

3 "The contracts with successive execution and which depend on the future presuppose that the circumstances remain unchanged (t.n)"'.
} 
mechanisms for adapting contractual relations, over time. Given the evolutions of some factors that cannot be foreshadowed by the parties at the time of conclusion of the contract, keeping it in its original form could be deeply unfair. However, the issue of monetary devaluation and its negative effects has been strikingly brought to the attention of jurists, the perpetuation of wartime economic instability and inflation forced doctrine and jurisprudence to explicitly address the foundations of the theory, even if it was not legislatively referred to ${ }^{4}$.

The vision in the Romanian law on this theory began to take shape with the admission of Lascăr Catargiu's action against Bercovici Bank. Therefore, the first case of admission of Unpredictabiliy circumstances at national level, settled by the Ilfov Court, Commercial Section I, by judgment of 11 May 1920, marked a huge step towards accepting that, under pressure from the economic environment, circumstances existing at the time of the execution of the conventions. The impossibility of amending a contract concluded on the basis of objective data existing at the time of the conclusion of the contract would mean giving absolute value to circumstances which, by their nature, are characterised by dynamism ${ }^{5}$.

Relevant is one of the considerations of the judgment, which stated that:

"if [...] totally exceptional events intervened and which changed the situation up to that point, causing the balance to be broken by the creation of excessive advantages on the one hand, or ruinous losses on the other, and if those events could not be foreseen on the date when the convention was concluded, it is fair for the parties to be exhonerated of their obligations".

It is noted that that decision opened the possibility of modifying the contractual relationship, based on equity considerations.

It is interesting to note the relationship between the principle of binding force and the theory of unpredictabiliy over a century: from 1920 - the admission of the theory of unpredictabiliy- until 2011 - when it was enshrined as a real exception to the principle of binding force in the new Civil Code ${ }^{6}$.

In 2011, the game of mutual influence and contradiction between doctrine and jurisprudence ended by regulating, as a real exception to the principle of binding force, the unpredictabiliy, the seat of the matter being included in art. 1271 et seq. Civil Code.

The unpredictabiliy has become a topical issue with its regulation in art. 1271 of the Civil Code, since, until then, the contract seemed to be the law of the parties. Until then, on the old Civil Code, although there was no express regulation of unpredictabiliy, the doctrine and jurisprudence accepted its existence, starting from the provisions of art. 970 of the old Civil Code, conventions must be executed in good faith, they oblige not only to what is expressed in themselves, but to all consequences, what fairness, custom or law gives the obligation by its nature,

\footnotetext{
${ }^{4}$ Burzo (1998) at 67.

${ }^{5}$ Togan (2017) at 4.

${ }^{6}$ Regarding the period after 1989 and until the adoption of the New Civil Code, an attempt was made to mitigate the rule of compulsory contracts. Although the theory of imprevision was rejected, the possibility of readjusting contracts through the freely expressed agreement of the contracting parties was legally enshrined.
} 
good faith and fairness being the starting point for mitigating the principle of binding force of the contract from art. 969 of the old Civil Code. At the same time, a series of special legal provisions were adopted through which special unpredictabiliy hypotheses were regulated, with limited applicability to the respective fields ${ }^{7}$.

Good faith was also central to the judgment of the Quebec Court of Appeal, delivered on 1 August 2016 in the Case Churchill Falls (Labrador) Corp. v. Hydro-Québec, 2018 SCC 46, maintained in 2018 by the Supreme Court of Canada, which examines the possibility of applying the unpredictabiliy and adapting the contract in the absence of a text of law that expressly enshrines it, based on the principle of good faith. The reasoning identified in this decision seems to be similar to that set out by the Constitutional Court in Decision no. 623/2016 regarding the exceptions of unconstitutionality of Law no. 77/2016 on the payment of real estate in order to settle the obligations assumed through loans, as well as the Decision of the Constitutional Court no. 15/2017 regarding the exception of unconstitutionality of the provisions of art. 3, art. 8, art. 10 and art. 11 of Law 77/2016, by which the constitutional contentious court placed the institution of unpredictabiliy and under the rule of the old Civil Code, apparently bypassing the rules of application in time of the civil law from art. 6 of the new Civil Code ${ }^{8}$ and from art. 107 of Law 71/2011 for the implementation of the new Civil Code ${ }^{9}$, showing only that this mechanism was applicable under the old Civil Code, in a similar form.

Renouncing the Francophone legal tradition, the Romanian legislator expressly regulated the unpredictabiliy as an exception to the principle of the binding force of the contract in art. 1,271 para. (2) Civil Code. The source of inspiration in this matter is represented by the vision of the German legislation and doctrine on the possibility of admitting the judicial review of contracts for unpredictabiliy, as well as by the international model of uniform regulation of unpredictabiliy provided by UNIDROIT $^{10}$, The Principles of European Contract Law ${ }^{11}$, Common frame of reference for European contract law. The conditions provided in art. 1,271 para. (2) - (3) are proof of the acquisition by the national legislator of this internationally promoted guideline on the existence of the contract ${ }^{12}$.

\footnotetext{
${ }^{7}$ See, for example, Law no. 8/1996 on copyright and related rights; Government Ordinance no. 42/1997 regarding the naval transport; Law no. 195/2001 on volunteering; Government Ordinance no. 5/2001 regarding the order of payment procedure.

${ }^{8}$ According to which "The provisions of the new law apply to all acts and deeds concluded or, as the case may be, produced or committed after its entry into force, as well as legal situations arising after its entry into force".

${ }^{9}$ According to which "The provisions of art. 1271 of the Civil Code regarding imprevision applies only to contracts concluded after the entry into force of the Civil Code".

${ }^{10}$ Art. 6.2.1-6.2.3 of the UNIDROIT Principles provided for the revision or renegotiation obligation based on a hardship clause implied in all contracts in which the hardship hypothesis was not excluded.

${ }^{11}$ The principles of the European contract law are a set of rules created by reputable legal specialists from European Union countries under the auspices of the Commission on European Contract Law (The Lando-Commission) and aim to standardise the European contract. See http://www.jus.uio.no/lm/eu.contract.principles.parts.1.to.3.2002/6.111.html for art. 6.111.

${ }^{12}$ Seperiusi-Vlad (2020) at 49.
} 


\section{Provisions of Domestic Law}

The name "theory of unpredictabiliy", under which this theory is known today in national law, was borrowed from French doctrine where the effects of changing circumstances were analysed under the title "la théorie de limprévision", probably to emphasise the key element, due to changing circumstances and breaking the contractual balance: the occurrence of an unpredictable event.

The binding force of the contract, a principle also known as pacta sunt servanta, as a fundamental principle that governs its effects between the parties, imposes on them the obligation to strictly perform the duties they have assumed, justified by the need to ensure stability and security in itself, as well as for reasons of justice and fairness between these parties. To demand full compliance with the contractual provisions in conditions of economic stability is absolutely natural and any deviation from them would harm the community in general. But to claim the same if unexpected circumstances overturn or distort the parties' expectations at the time of the conclusion of their contract and result in a clear disproportion of the benefits they owe, has the same negative effect on the community and the sense of justice in general.

Although the pacta sunt servanda and rebus sic principles are seemingly antagonistic, they complement each other, the latter operating as an exception to the first, with the common goal of ensuring the legal security of contracts ${ }^{13}$.

Contracts with successive execution and contracts affected by a suspensive term of execution are exposed, during their existence, to random circumstances whose origins are in the economic situation and, especially, in monetary fluctuations (depreciation of the purchasing power of money). When a contract is concluded, especially during periods of relative monetary stability, the contracting parties shall assume obligations in view of the circumstances or economic realities of the time. But, if, after the conclusion of the contract and before its execution, unforeseen events occur (war, crises, revolution, etc.), serious imbalances may occur between the value of the parties' benefits. The Covid-19 pandemic, the global health crisis that has paralysed the development of trade relations and contractual relations, has recently been included in the category of these unforeseen events, putting the parties in an impossible situation.

In the face of the chronicity of the evil called inflation, respectively monetary depreciation $^{14}$, the strict application of the principle of binding force of the contract revealed a risk of ruin for one of its parties and a cause of enrichment for the other.

In the absence of an express legal definition, unpredictabiliy has been qualified in law as damage suffered by one of the contracting parties as a result of the serious imbalance of value between its services and the other party's consideration during performance of the contract, caused by currency fluctuations or of other circumstances $^{15}$.

\footnotetext{
${ }^{13}$ Ungureanu (2015) at 49.

${ }^{14}$ The intervention of the deflation process, that is the increase of the purchasing power of money, is not excluded either.

${ }^{15}$ Pop, Popa \& Vidu (2013) at 153.
} 
Currently, the application of the theory of unpredictabiliy requires the intervention of the judge to restore the broken contractual balance due to unforeseen circumstances of the parties at the conclusion of the contract and unpredictable from the same date, in the absence of express clauses or legal provisions to enable it to review the contract.

The legal norm that we have in mind in our research is included in art. 1271 of the Civil Code, which provides that

"(1) The parties shall be bound to execute their obligations even when such execution has become more onerous, either because of an increase in the execution costs or because of a decrease in the performance value.

(2) However, when the contract execution has become excessively onerous due to an exceptional change in circumstances, which would render the binding of the debtor to fulfill the obligation evidently unjust, the court of law may order: a) the adaptation of the contract in order to equitably distribute between the parties the losses and benefits resulting from the change in circumstances;

b) the termination of the contract at the moment and under the conditions established under it.

(3) The provisions of para. (2) shall applicable only if: a) the change in circumstances occurred after the conclusion of the contract; $b$ ) the change in circumstances, as well as their extent, were not and could not have been reasonably considered by the debtor upon contract conclusion; $c$ ) the debtor did not undertake the risk of the change in circumstances and they could not have been reasonably considered to have undertaken that risk; d) the debtor tried, within a reasonable period and in good faith, to negotiate the reasonable and equitable adaptation of the contract."

The text of article 1271 is an exception to the binding force of the contract, provided in art. 1270 of the Civil Code, a text which stipulates that:

"(1) The valid contract concluded has the force of law between the contracting parties. (2) The contract is modified or terminated only by the agreement of the parties or for reasons authorised by law"

Thus, we can notice that the limitations brought to the principle of pacta sunt servanda are essential to ensure the fairness of the contractual relationship in case of factually unfavorable situations for one of the parties. The parties are required to perform their obligations even though the execution has become more onerous, either due to the increase in the execution of their obligation or due to the decrease in the value of the consideration (application of the principle of binding force of the contract), thus highlighting the principle of monetary nominalism ${ }^{16}$.

However, art. 1271 of the Civil Code states that not every change in the consistency of the obligation occurred after the conclusion of the contract leads to the possibility of resorting to the mechanism of unpredictabiliy, but the text states that the change must be "exceptional", meaning it must be of such magnitude that the obligation to become "excessively onerous", 17 .

\footnotetext{
${ }^{16}$ Holban \& Marțincu (2018) at 7.

${ }^{17}$ Bârsan (2015) at 80.
} 
As previously mentioned, the second paragraph of art. 1271 of the Civil Code refers to the "execution of the contract" which has become excessively onerous due to the exceptional change of circumstances, changes which, according to the third paragraph of letter a), intervened after the conclusion of the contract. It follows, therefore, that the performance of the contractual obligations must take place either at a certain time after the conclusion of the contract or periodically. Therefore, the unpredictabiliy cannot be applied to contracts with immediate (instantaneous) execution unless they are affected by the modality of the suspensive term or condition. Instead, the preferred category of contracts to which unpredictabiliy is addressed is that of contracts with successive execution, contracts whose existence is usually long-term.

The specialised literature also expressed the same opinion, showing that the unpredictabiliy may have an impact on certain types of contracts that may be affected by the change of circumstances considered by the parties at the time of their conclusion, such as: (i) synallagmatic contracts, for a fee and successive (long-term) performance, (ii) synallagmatic contracts, for a fee and uno ictu performance, if the unpredictabiliy situation arises before the performance of the contractual obligations, (iii) certain unilateral contracts, if the unpredictabiliy situation makes the execution of the debtor's obligation excessively onerous for him, (iv) the contracts free of charge, under the conditions of art. 1,006, art. 1,007 and art. 1,008 Civil Code ${ }^{18}$.

The difficulty in applying the theory of contingency as a basis for the judge's ability to amend a contract lies precisely in the fact that the law uses notions with a certain degree of relativity such as: "more onerous obligation" (when the contract must be performed even in these conditions) and "excessively onerous" respectively (when the contract may be re-established under the rebus sic stantibus rule), without providing a clear distinction, which may lead to inconsistent judicial practice. In the literature, it is considered that an obligation can be qualified as excessive, when it is clear that one of the parties would not have contracted if it had foreseen this situation before the conclusion of the contract.

In the event that certain contractual obligations have become excessively onerous, certain conditions must be met for the admissibility of the unpredictabiliy. Article 1271 para. (3) lists these conditions, which must be met cumulatively:

A first condition presupposes that the change of circumstances occurred after the conclusion of the contract, otherwise, if it had already occurred at the date of the conclusion of the contract we are no longer dealing with unpredictabiliy, but with the initial impossibility of execution, which is now subject to a different regulation, contained in art. 1227 of the Civil Code, or even an error, as regulated by art. 1207 Civil Code. The moment of obvious disproportion between the consideration thus has a special role, because it distinguishes betweenu and other legal institutions, such as injury -vice of consent.

The phrase "change of circumstances" has a complex content, as it encompasses in its meaning both the idea of an event and the fact that the event produced a change in the contractual status quo, meaning that the elements taken into account in determining the value. goods or services which are the subject of

\footnotetext{
${ }^{18}$ Sandar (2013), at 61.
} 
the contract, elements according to which the parties have established the initial contractual balance. Also, the change of circumstances must be effective and not hypothetical.

The second condition that follows from the provisions of art. 1271 Civil Code implies the need that the change of circumstances, as well as their extent, was not and could not reasonably have been taken into account at the time of the conclusion of the contract. The condition of unpredictabiliy of the change of circumstances results explicitly from the provisions of art. 1271 para (3) letter b) Civil Code, referring to a reasonable unpredictabiliy, meaning that to some relative extent, and not absolute, which leads to the essential difference between unpredictabiliy and force majeure, in which case we discuss about an absolute and insurmountable unpredictabiliy, according to art. 1251 para. (2) Civil Code. Also, if the parties have provided at the time of the conclusion of the contract the possibility to modify the contract and have introduced in the contract either an indexation clause or a hardship clause, the unpredictabiliy can no longer be successfully invoked.

The third condition presupposes that the debtor has not assumed the risk of changing circumstances or is not reasonably considered to have assumed such a risk. This condition is subsequent and complementary to the previous condition, and the legislator understood to emphasise by these two hypotheses in which the unpredictabiliy does not work: in one of them, the debtor has expressly assumed the risk of an unforeseen event and in the second case, the assumption of the risk of the unforeseen event is inferred by way of interpreting the contract.

Another condition implies that the debtor has tried, within a reasonable time and in good faith, to negotiate the reasonable and fair adjustment of the contract. The debtor has the duty to notify the creditor of the occurrence of the unforeseen event and to try on this occasion to negotiate the rebalancing of the contract affected by the unpredictabiliy. Modification of the contract by agreement of the parties is an application of the mutuus consensus, mutuus dissensus, mutuus consensus, mutuus dissensus principle, not a result of unpredictabiliy.

As it results from the text of art. 1271 letter d) of the Civil Code, it imposes on the debtor two conditions that must be circumscribed his attempt to negotiate the contract, conditions that must be proved before the court, if the conciliation attempt failed. Thus, the first condition imposed on the debtor is to prove that he tried to negotiate the contract in order to adapt it to the new circumstances imposed by the occurrence of the unpredictabiliy within a reasonable time, which is, in the absence of an express legal provision to determine the minimum or maximum duration, a question of fact which may put the debtor in difficulty if he has to prove to the court his attempt to negotiate the contract within a reasonable time. With regard to the timing of the negotiation of the adjustment of the contract, it was stated that it is necessary that these negotiations should take place as close as possible to the intervention of the contractual imbalance ${ }^{19}$.

This condition has raised many questions in judicial practice, from the perspective of its nature as a precondition for notifying the court or a substantive condition for the incidence of unpredictabiliy, and the literature has statued that the

\footnotetext{
${ }^{19}$ Lozneanu, Barbu \& Bebi (2012) at 54.
} 
provision established by art. 1271 para. (3) Civil Code establishes a mandatory prior procedure for the parties for the conventional review of the contract, before notifying the court, the non-fulfillment of this condition constitutes a fine of inadmissibility if it is formulated in court without fulfilling this preliminary procedure $^{20}$.

In the same sense, it was stated that this condition does not represent a condition of unpredictabiliy, but rather a condition for notifying the court, a preliminary procedure similar to the procedure of direct conciliation in cases and requests in commercial matters, provided by art. 720 ind. 1 of the old Code of Civil Procedure.

Next, we will reproduce some other conditions that are implicit in the analysis of the legal provisions and that have been indicated in the doctrine. Thus, within the provisions of art. 1271 para. (2) Civil Code, which states that the execution of the contract must have become excessively onerous "due to an exceptional change of circumstances" is the condition regarding the exceptional nature of the change of circumstances.

In order to establish the exceptional character of an event, the reporting must not be done in abstracto, meaning by reference to generic events such as wars, revolutions, strikes, yet the assessment must aim at a concrete event.

Also regarding the exceptional circumstances that disturb the contractual balance, in the recent literature it has been stated that currency fluctuation does not constitute an unpredictable event from the perspective of applying unpredictabiliy in the case of loan agreements with banking institutions, in the increasingly current context of abusive causes contained in these conventions ${ }^{21}$.

Another condition concerns the transformation of the debtor's obligation into an excessively onerous one, which clearly results from the content of art. 1271 para. (2). The meaning of the term "onerous" is explained in the first paragraph of the same article, which, referring to obligations that have become "more onerous", states that this happens "either due to increased costs of fulfilling its obligation, either due to the decrease in the value of the consideration".

A last condition debated in the doctrine refers to the absence of the debtor's fault regarding the change of circumstances or the extent of their effects. Although this condition does not explicitly result from the content of Article 1271 of the Civil Code, existing doctrinal controversies regarding the necessity or usefulness of retaining such a condition, most of the doctrine considers this issue as necessary to retain the unpredictabiliy.

The effects of unpredictabiliy are regulated by art. 1271 para. (2) of the Civil Code, which stipulates that once the conditions of unpredictabiliy are met,

"if the performance of the contract has become excessively onerous due to an exceptional change of circumstances which would make it manifestly unfair to oblige the debtor to perform the obligation, the court may order the adaptation of the contract in order to distribute equitably between the parties the losses and benefits resulting from the change of circumstances."

\footnotetext{
${ }^{20}$ Ludusan \& Puie (2013) at 24.

${ }^{21}$ Motica \& Bradin (2015) at 546.
} 
The adaptation of the contract involves the direct intervention of the court, so that, by the judgment given, the economic values of the parties' services are modified in order to restore the disturbed contractual balance.

The court may adjust the contract either by acting on the value of the benefits or by amending certain contractual clauses. If the last option of adapting the contract is chosen, the court will have to take into account the fact that, through the correction it will make to the contract, it cannot innovate, meaning that the court is forbidden to rewrite the contract or change its nature by imposing on the parties a new and completely different contract, in which its object has been changed or completely new obligations have been imposed.

Another measure that the court can take if it finds that the conditions of unpredictabiliy are met is to order "the termination of the contract, at the time and under the conditions it establishes", being a termination with effects for the future.

However, we state that the court will not be able to replace the will of one of the parties that has assumed insufficiently described rights, without deadlines, without delivery obligations, without conditions, but will intervene only in those cases where external factors, whose evolution has not been correctly subject to the agreement of will, radically transforms the amount of rights and obligations of the convention, affecting the initial contractual balance ${ }^{22}$.

When we talk about the judicial review of the contract affected by the unpredictabiliy by reducing the benefits, even if we keep in mind that we are not formally talking about a partial termination, it is impossible not to notice that the legal act "suffers" the same legal fate, being partially abolished on the reason of imbalance in consideration ${ }^{23}$.

The current legislation does not offer solutions regarding the possibility of suspending the contract affected by unpredictabiliy, and as noted in the Constitutional Court Decision no. 623/2016, the answer seems to be negative, as the conditions of applicability must be interpreted stricto sensu and the same solution would be required in terms of effects.

\section{Elements of Comparative Law}

Beyond the borders of domestic law, it is not surprising that we can identify the regulation of an institution similar to the one called unpredictabiliy in our domestic law, because as we have already shown, many states have adopted the theory of unpredictabiliy long before our country.

\footnotetext{
${ }^{22}$ "If a contract for repair works has not established a deadline for the delivery of the repaired property, any attempt to establish, even by the court, a deadline, can only be made with the defeat the principle of freedom of will of the parties and in violation of the principle of legality. According to this principle, the court is itself obliged to respect the law, and, in this case, the law is given by art. 969 of the Civil Code (art. 1169 NCC), the contract is the law of the parties, and if the parties have not established a term, the court cannot add to the contract of the parties. Therefore, the High Court has ruled that, if no contractual term has been established, it cannot be considered that the work was delivered late and, consequently, no damages can be awarded for this reason". (Decision no. 373 of February 1, 2012 ruled on appeal by the Second Civil Section of the High Court of Cassation and Justice having as object claims)".

${ }^{23}$ Lazăr (2016) at 13.
} 
For example, in the English law, the contractual unpredictabiliy is found under the broader concept of frustration, which, beyond the name that suggests the condition of one of the contracting parties when it realises how much the circumstances have changed since the time of concluding the contract, in the English law designates that sphere of impossibility of execution, among which, along with unpredictabiliy, is the force majeure, $\operatorname{too}^{24}$.

The German law does not regulate a theory perfectly corresponding to the contractual unpredictabiliy in the Romanian law, being a broader concept, similar to that found in the English law, under the name of Geschaftsgrundlage, the regulation being found in art. 313 of the German Civil Code of 2000, being a theory of disruption of the contractual basis, respectively that situation occurred in a totally unforeseen way, which completely destabilises the contractual balance ${ }^{25}$.

The Italian law has a general regulation in art. 1467 and 148 of the Italian Civil Code, the concept being called eccesiva onerosita and the remedy implying a termination of the contract that has lost the balance of benefits ${ }^{26}$.

In France, until the emergence of the legislative reform in 2016, the principle pacta sunt servanda was applied without exception by the courts, which had no legislative basis to apply the doctrinal theory of unpredictabiliy. Starting with October 1, 2016, the unpredictabiliy is regulated by art. 1195 of the French Civil Code, almost identical conditions to those found in our law being provided ${ }^{27}$.

The Greek civil law provides in art. 388 that the unforeseen change of the circumstances taken into account at the conclusion of the contract may allow the reduction of the debtor's performance or the termination of the contract, being practically an application of the principle of good faith in the contractual relations.

This regulation found in the Greek Civil Code is similar to that of our domestic law, requiring several conditions to be applicable, including the synallagmatic nature of the contract, the unforeseen change in circumstances that the parties considered in the conclusion of the contract, the change of circumstances is due to an exceptional and unforeseen event and this has led to a transformation of the obligation of one of the parties into an excessively onerous one ${ }^{28}$.

\section{Unpredictabiliy in the Context of Covid-19 Pandemic}

One of the most debated issues at the international level today was the Covid19 pandemic, especially the legal, economic and social effects of this pandemic. As already mentioned, at the time of concluding a contract, especially in periods of relative monetary stability, the contracting parties undertake in the light of the circumstances or economic realities of the moment. Yet, the economic reality also shows that during the execution of the contract unforeseen events can occur, for example, war, crises, revolution, pandemic, which can generate a series of

\footnotetext{
${ }^{24}$ Dumitriu (2013) at section 4.

${ }^{25}$ Zimmermann (2002) at 2.

${ }^{26} \mathrm{https}$ ///www.normattiva.it/uri-res/N2Ls?urn:nir:stato:regio.decreto:1942-03-16;262

${ }^{27}$ The French provision being available at: https://www.trans-lex.org/601101/_/french-civilcode-2016/\#head_62.

${ }^{28}$ Iftimie (2015) at 133 .
} 
consequences, such as: shortage of goods, decrease in the purchasing power of money through inflation, exaggerated increase in prices, services and wages. Hence, it is a single step towards the economic chasm to which a party is exposed if serious imbalances can occur between the value of the parties ${ }^{29}$.

Naturally, the world's attention is currently focused on COVID-19, the disease caused by the SARS-coV-2 coronavirus, which appeared in China at the end of 2019 and has so far spread to over 150 states. The health crisis created by the spread of this virus has caused the disruption of economic activity and destabilisation of legal relations, worldwide being enough victims to make the World Health Organisation, on 11.03.2020, declare that we are in the presence of a pandemic - qualification that has led most states to take measures to prevent the spread of the virus, which has important legal effects in most areas. The analysis of the nature and legal effects of the pandemic generated by the SARS-CoV-2 coronavirus is a recent and ongoing concern of legal specialists, in order to anticipate potential contractual and/or litigious situations that may arise during the state of emergency or even after its cessation (including by the cessation of some of the effects of the special, derogating legislation, adopted during this period, and, therefore, after the restoration of the domestic legal order).

In order to combat and prevent the spread of the Sars-CoV-2 virus, a state of emergency was ordered throughout Romania (initially, by Decree no. 195/2020, later extended by Decree no. 240/2020), and this exceptional context has led to the gradual application of restrictive measures, which generated a major shock for the national economy and consequences with a significant impact on the economic situation of debtors, individuals or legal entities, whose incomes have decreased considerably.

In the same vein, the restrictive measures established by military ordinances began with banning the movement of individuals, closing the country's borders, suspending all trade flights in countries severely affected by the pandemic (with more than 10,000 people confirmed positive with this virus), closing restaurants, cafes, bars and terraces, banning gatherings of more than 3 people (initially, this number being gradually increased), including banning events such as weddings, baptisms, parties, etc.)

Clearly, the impact of the legislative measures and restrictions adopted to limit the spread of the COVID-19 epidemic has affected ongoing contracts, mainly works, services and transport contracts, but not only.

Thus, amid increasingly drastic measures, the issue of how to exonerate civil liability cases has been raised, given the risks currently present, mainly determined by the following factors: restrictions imposed by the Government; lack of employees, determined by isolation/quarantine; interruptions/delays in the execution of contractual obligations.

\footnotetext{
${ }^{29}$ Andries (2016) at 28.
} 


\section{Methodology/Material and Methods}

Notions such as force majeure, fortuitous event and unpredictabiliy are already discussed in ongoing contracts. The answer to the question whether the COVID-19 pandemic and the establishment of the state of emergency automatically fall under one of the three notions mentioned above, is not a valid general answer, each situation having to be analysed in the light of its particularities. Moreover, in the context of this exceptional situation, one-size-fitsall approaches must be viewed with caution, given the different limitations and legal consequences that each situation entails ${ }^{30}$.

As it results from the conditions already analysed, the unpredictabiliy is not to be mistaken for force majeure or fortuitous case, as exonerating causes of liability. The unpredictabiliy is not to be mistaken for an impossibility of performance, but it concerns the situation in which the fulfillment of the contractual obligations is still possible, but it has become excessively onerous in relation to the counterparty's consideration.

There are multiple situations in which the spread of the pandemic will have the effect of force majeure or fortuitous event, in that it has made the execution of the contract objectively impossible. Moreover, the public authorities have already instituted measures to block the activity of certain categories of professionals, coming to their aid with measures such as postponing the payment of rent and utilities, under the conditions of art. X of the E.G.O. no. 29/2020 ${ }^{31}$. However, these measures are not generally applicable, as economic market actors have not been uniformly affected din E.G.O. no 29/2020 32 .

As we have already shown, in order to highlight its basis and purpose, contractual unpredictabiliy must be distinguished from a number of other similar legal figures, such as injury, error, randomness, force majeure, resolutive condition or repair of unforeseeable damage.

For our study, especially for the effect of the pandemic, the greatest interest is the difference between unpredictabiliy and force majeure, this institution which, in terms of its character, is irresistible, invincible and inevitable.

\footnotetext{
${ }^{30}$ Strambei (2020) at 11.

${ }^{31}$ Emergency Ordinance no. 29 of March 18, 2020 on some economic and fiscal-budgetary measures Art. X (2) By derogation from other legal provisions, in the ongoing contracts, other than those provided in para. (1), concluded by the small or medium enterprises provided in para. (1), force majeure may be invoked against them only after the attempt, proven by documents communicated between the parties by any means, including by electronic means, to renegotiate the contract, to adapt their clauses taking into account the exceptional conditions generated by the state of emergency. (3) It is presumed to constitute a case of force majeure, in the sense of the present emergency ordinance, the unpredictable, absolutely invincible and inevitable circumstance referred to in art. 1,351 para. (2) of the Civil Code, resulting from an action of the authorities in applying the measures imposed by the prevention and control of the pandemic caused by COVID-19 coronavirus infection, which affected the activity of small and medium enterprises, damage attested by the emergency certificate. The presumption may be rebutted by the interested party by any means of proof. The unpredictability is related to the birth of the affected legal relationship. The measures taken by the authorities in accordance with the normative act that established the state of emergency will not be unpredictable.

${ }^{32}$ Şeulean (2020) at 2.
} 
As we have already anticipated, the two institutions have a common character through the sphere of constitutive events, both of unpredictabiliy and force majeure. From here another similarity can be emphasised, which concerns the unpredictability of these situations. The unpredictability of force majeure is such as to remove the debtor's liability only if he was unable to objectively foresee both the occurrence of the event and the adverse effects which it caused. In the case of unpredictabiliy, the feature of unpredictability which gives rise to a serious disturbance of the contractual balance is essential.

Another similarity is provided by the effect on the contractual liability of the party affected by the intervention of the event which determines the removal of liability, the contractual obligation will no longer be performed in the agreed terms.

Finally, exposed to a case of unpredictabiliy or force majeure, the parties are obliged to negotiate, as a form of the obligation of cooperation that must exist between them during the performance of the contract.

As can be seen from the definition given by the Civil Code to force majeure, it is specific to its absolutely invincible and inevitable character, which highlights the extent of the prejudicial event that occurred unexpectedly. Therefore, in the case of force majeure, irresistibility and inevitability are two conditions that must be met cumulatively, because even if the event could have been anticipated objectively, its occurrence and its devastating effects generated could not have been avoided, despite the fact that the debtor has taken all necessary measures ${ }^{33}$. The doctrine states that in the case of unpredictabiliy, "an irresistibility of a lower degree can be retained, in the sense of the impossibility of removal, of resistance to excessive onerousness or of the drastic diminution of benefits.

As regards the effects on the contract, the occurrence of an event of force majeure entails the legal impossibility of performance of the obligation assumed. In the case of contractual unpredictabiliy, the affected party is not unable to execute or accept the service, but the excessive burden of the obligation or the drastic decrease of the service to be received occurs.

The different status of incidental remedies is a factor generating a new difference. In the case of force majeure, the remedy for the party exonerated from liability shall take into account the duration and magnitude of the event that occurred - the total or partial termination or suspension of the contract. On the contrary, contractual unpredictabiliy has a specific remedy, to adapt the contract to the new circumstances, in order to preserve it.

Finally, the force majeure is a real exception to the principle of binding force of the contract, while the unpredictabiliy is an apparent exception, which reconfirms this principle and gives substance to the obligation of good faith seen as loyalty in the performance of contracts.

Therefore, in the field of civil law, the pandemic is not, automatically and abstractly, a case of force majeure or a fortuitous event, nor does it entail the ope legis application of the unpredictabiliy.

However, given that the COVID-19 pandemic has an undeniable impact on the civilian circuit, affecting the security of ongoing legal relations, the three

\footnotetext{
${ }^{33}$ Boilă, Baias, Chelaru, Constantinovici \& Macovei (2012) at 1492.
} 
institutions could be applied, but a case-by-case assessment will be needed to conclude whether and in which to what extent their conditions are applicable to a given situation.

We must not forget that the contractual will of the parties is sovereign and may remove the incidence of cases of force majeure, fortuitous event and, in particular, unpredictabiliy (art. 1351 para. (1) and art. 1271 para. (3) letter c) of the Civil Code), in many matters being such usual contractual clauses to remove the application of the institutions in question. In the conditions of excluding the possibility to invoke them, however, the party which, according to the relevant provisions of the Civil Code could have been exonerated from liability, so which assume the risk of events likely to attract the application of the institutions in question, will be required to fulfill the contractual obligations or repair the damage resulting from their non-performance ${ }^{34}$.

As such, if we are not in a fortuitous impossibility of execution due to force majeure or fortuitous event, but the emergency situation due to the SARS-CoV-2 pandemic can be considered an exceptional change of circumstances in the execution of the benefits of one of the parties, which become excessively onerous compared to the circumstances considered at the date of signing the contract, likely to affect the contractual balance, the party affected by this change could request the court to adapt the contract, pursuant to art. 1271 Civil Code.

\section{Findings/Results}

Further, it is necessary to pass the pandemic through the filter of the conditions already exposed to retain the incidence of unpredictabiliy. Thus, with regard to the condition that the change of circumstances occurs after the conclusion of the contract, we show that the spread of this virus, together with all measures taken by the states after the official declaration of the pandemic is an exceptional change that can be invoked in concluded contracts and still not executed on the date of the official declaration of the pandemic by the World Health Organisation, respectively 11.03.2020.

Regarding the condition of unpredictability of changing circumstances and their extent at the time of concluding the contract, it is clear that the pandemic is an external and unpredictable event, but some nuances can be made about when this phenomenon of virus spread became known to people in Romania. Thus, although it cannot be stated with certainty that the evolution of the pandemic became predictable with the media coverage of the effects of infection with this virus and the number of people who died in China due to this virus, the same cannot be said about the time of the spread of this virus in Italy, or more, at the time of the declaration of the pandemic by the WHO. Specifically, this condition will not be met in all cases, a verification being made by reference to the time when the parties to the contract knew of the possibility of changing circumstances due to the Sars-CoV-2 virus.

\footnotetext{
${ }^{34}$ Preda (2020) at 2.
} 
Subject to the condition that the debtor has not assumed the risk of a change in circumstances or is not reasonably considered to have assumed such a risk, we recall that the parties are free to stipulate certain clauses limiting the contractual liability, as well as clauses by eliminating the possibility of invoking unforeseen events in the event of changes. However, given this condition in the current context, it is easy to imagine a contractual clause whereby the parties choose to exclude the incidence of fortuitous event or force majeure (or expressly, the pandemic). For example, several people were surprised to find that in the contracts with the travel agencies for the purchase of holiday packages there were clauses excluding fortuitous events, force majeure and unpredictabiliy in the event of events such as a pandemic, clauses which they did not analyse sufficiently thoughtfully in the given context.

The condition that the debtor has tried, within a reasonable time and in good faith, to negotiate the reasonable and fair adjustment of the contract does not raise issues in this analysis, regarding the debtor's conduct after the pandemic. In this context, we point out that a large part of the contracts affected by the change of circumstances taken into account at the time of their conclusion were renegotiated and/or rebalanced by the parties, following the negotiations, in order to bear fairly the losses suffered as a result of the changing economic context. For example, in the case of a lease contract with a legal entity, which in turn subleased Airbnb to tourists, the measure restricting the freedom of movement of people outside the country led to the cessation of all reservations made by the tourists on that platform, with the consequence of losing the profit from which the legal person pays the rent established by the contract.

Finally, reviewing the implicit conditions shown above, we appreciate that it is clear that the condition of the exceptional nature of the change of circumstances is met. Thus, the whole of humanity was surprised by the appearance of this pandemic, which is, in itself, an exceptional event, being compared to the Spanish flu that devastated the whole world last century and had tragic effects on those times.

Also, as regards the transformation of the debtor's obligation into an excessively onerous one, the verification of this condition is to be made in each individual case. A common situation is when the debtor's income has been considerably diminished (either due to technical unemployment or dismissal), which prevents him from either paying the bank loan installments, due rent, or continuing previous contractual relationships.

Another common situation concerned the freight transport, in particular crossborder transport contracts. As we have shown, the traffic restrictions were severe, at the border crossing points being established real epidemiological controls, along with the formalities of registration of persons transiting several countries, the purpose of transit and especially the final destination. Adding to all these controls and the fear generated by the possibility of contracting the virus in contact with other people in countries deeply affected by the pandemic (with about 1000 deaths per day), leading to the situation that transport companies did not have drivers available to assumes these risks for the same income as before the pandemic, which is why they requested significant salary increases. These additional costs 
incurred by transport companies have led to the transformation of pre-pandemic obligations into excessively onerous ones.

The situation generated by coronavirus could make many companies objectively unable to fulfill their contractual obligations to their trading partners. In such cases, the non-performance of the obligations could be excused by a situation of force majeure, which usually implies the existence of an objective, unpredictable, invincible and external event. An example would be the obligation to deliver a good in an isolated city, which cannot be entered.

As we have shown on the occasion of the delimitation between force majeure and unpredictabiliy, if for some situations of force majeure, they can justify the non-execution, others could only be in a situation that does not make the execution impossible, but only much more onerous. For example, if the city where the property in question is to be delivered is not isolated and entry into it is not blocked by the authorities, yet fulfilling the delivery obligation becomes much more expensive for the debtor - for example, the usual route used for deliveries is no longer valid, because it passes through blocked cities, and / or has to find other suppliers, because the ordinary one could no longer produce goods, it turns out that such a situation could radically increase the cost for the one who has to deliver a good. Yet there is nothing in the present case that would prevent the debtor (objectively) from fulfilling his obligation, but would only make it much more difficult for him to comply with his contractual commitments. In such situations, although he cannot use the excuse of force majeure, the debtor could still rely on the unpredictabiliy mechanism to obtain a remedy.

We consider that in the latter hypothesis we can talk about a potential contractual imbalance, which occurred as a result of the pandemic. The parties must negotiate in good faith, a context in which we consider that the disadvantaged party has to prove in concrete terms the excessive burden of its obligation.

Equally, a distinction must be made between unpredictabiliy and fortuitous impossibility of execution, in the light of the premise of each institution. For example, in one case, the Bucharest District 3 Court ruled that from the grammatical interpretation of the provisions of art. 1271 Civil Code, the intervention of the unpredictabiliy can be questioned only in the hypothesis in which the execution of the contract has become excessively onerous, or, in the case brought before the court, the obligation of the defendant to organise a wedding event with 150 people on August 22, 2020 has not become overly onerous, but has become impossible to enforce due to legal restrictions at the time.

Therefore, it is not excluded that the pandemic with COVID-19 is a case of unpredictabiliy, if the conditions previously analysed are met. The mere occurrence of this event, however, does not exempt the party invoking it from the obligation to prove concretely the contractual imbalance encountered, as well as the direct causal link between the occurrence of the pandemic and the situation thus created. 


\section{Conclusions}

The regulation of unpredictabiliy in the New Civil Code is certainly one of the great challenges brought by the legislator in the civil legislation of Romania. The current regulation appeared in the context of denying the intervention in the contract and evolved towards the possibility of the judge to adapt the contract, in order to rebalance it.

Used as a means of aligning economic and legal realities with the new challenges of the 21 st century, the theory of unpredictabiliy is intended to be a viable solution to ensure the completion of as many contracts as possible whose performance is jeopardised by the existence of a major imbalance between the parties, appeared after the conclusion of the contract.

However, adapting the theory of unpredictabiliy of our legal system does not appear to be easy, as the implementation of this theory will overlap with the legal regime of other legal or economic institutions, such as force majeure or credit, for example, a regime that should not be affected.

The current social and economic context has undergone significant changes due to the Covid-19 pandemic, meaning that the institution of unpredictabiliy also comes to help the contracting parties to save the contracts concluded before the pandemic, which were affected in the context of measures and restrictions taken by everyone.

In the matter of execution of the contractual obligations assumed before the declaration of the pandemic and, later, of the state of emergency, there is no generally valid solution, the contractual treatment finds - to a large extent - its solution, in the very clauses of the legal act which ascertains the obligatory relations, corroborated with the factual situation specific to each contracting party, in part. It is essential that we have established that the pandemic and the state of emergency regulated, followed by normative and administrative measures issued by the authorities, fall into the category of cases of force majeure lato sensu and the same causes can be the support, in particular situations, to invoke the fortuitous case by some persons (placed in such circumstances, by the force of the application of restrictive measures by the authorities) or, as the case may be, for invoking the unpredictabiliy.

We believe that it will be a test both for the participants in economic and legal life, as well as for the courts, which will have to rule impartially and professionally when called upon to assess the adaptation of contracts, in the context of ambiguous formulations of the legislator and in the absence of clear criteria for this mission, but especially in the context of the global difficulties posed by the pandemic that hit the world in early 2020.

\section{References}

Andries, M.C. (2016). Efectele schimbărilor climatice sub aspectul impreviziunii contractuale şi al imposibilităţii fortuite de executare' (The effects of climate change in terms of contractual contingency and fortuitous impossibility of execution) in Romanian Journal of Private Law 4:28-57 
Bakos, A. (2020). 'Unpredictabiliy, an alternative for companies that have difficulties in performing contracts, but can not invoke force majeure'. https://www.avocatnet.ro/ar ticol_54072/Impreviziunea-o-alternativ\%C4\%83-pentru-firmele-care-au-dificult\%C $4 \% 83 \% \mathrm{C} 8 \% 9 \mathrm{Bi}$-in-executarea-contractelor-dar-care-nu-pot-invoca-for $\% \mathrm{C} 8 \% 9 \mathrm{Ba}-$ major \%C4\%83.html.

Bârsan, C. (2015). 'Principiul nominalismului monetar și impreviziunea în contractul de imprumut de consumație având ca obiect o sumă de bani: asociere ireconciliabilăa?' (The principle of monetary nominalism and the unpredictability in the consumer loan contract having as object a sum of money: irreconcilable association?)' in Liber Amicorum Liviu Pop. Reform of Romanian private law in the context of European legal federalism, Bucharest: Judicial Universe Publishing House

Boilă, L. R., Baias F., Chelaru E., Constantinovici R. \& I. Macovei (2012). New civil code. Comment on Articles. Bucharest: C.H. Beck Press.

Bradin, F.V. (2018). 'Contractual Unpredictabiliy in the new Civil Code', PhD thesis, Faculty of Law, West University of Timișoara (Impreviziunea contractuală în noul Cod civil).

Burzo, M.E. (1998). 'The effects of monetary devaluation in patrimonial civil legal relations' $\mathrm{PhD}$ thesis, Faculty of Law, "Babeș-Bolyai" University Cluj-Napoca (Efectele devalorizării monetare în raporturile juridice civile patrimoniale).

Dumitriu, G.O. (2013). 'European contract law. Realities. Influences. Field of application.' Bucharest: C.H. Beck Press (Gina Orga-Dumitriu, Dreptul european al contractelor. Realităţi. Influenţe. Domeniu de aplicare, Ed. C.H. Beck, Bucureşti.

Holban, D. \& I. Marțincu (2018). "Unpredictability. The "icons" of the hazard of the unjust advantage and the emotions of Roman Envy' paper presented at the meeting of Robertianum Center for Private Law, Faculty of Law of Al. I. Cuza from Iași, 17 May 2018 (Impreviziunea. "Pictogramele" hazardului avantajului injust și emoțiile Invidiei romane).

Iftimie, E. (2015). 'Good faith in Greek civil code' in Journal of Public Administration, Finance and Law, Special Issue 2/2015:133-141

Lazăr, R. (2016). 'Injury and unpredictability - distinct hypotheses of reduction of benefits due', in Acta Universitatis Lucian Blaga (Leziunea şi impreviziunea - ipoteze distincte de reducere a prestatiilor datorate).

Lozneanu, V., Barbu V. \& P. Bebi (2012). 'Discussions about the exception of the lack of prior procedure in matters of unpredictabiliy'. Romanian Journal of Compulsory Execution (Discuţii asupra excepţiei lipsei procedurii prealabile în materia impreviziunii). 9:54-63.

Ludusan, F. \& O. Puie (2013). 'Aspecte privitoare la procedura prealabilă a negocierii părţilor pentru adaptarea contractului în cazul apariţiei unor cazuri de impreviziune. Condiţie de exercitare a acţiunii în justiţie' (Aspects regarding the preliminary negotiation procedure of the parties for the adaptation of the contract in case of unforeseen occurrence. Condition for starting trial) in Romanian Pandects Journal 4:24-38.

Motica, R.I. \& V.F. Bradin (2015). 'Impreviziunea și clauzele abuzive în cazul împrumuturilor bancare acordate în valuta' (Unpredictabiliy and abusive clauses in the case of bank loans granted in foreign currency) in Liber Amicorum Liviu Pop. Reform of Romanian private law in the context of European legal federalism. Bucharest: Judicial Universe Press.

Preda, M. (2020). 'COVID-19 pandemic - between force majeure, fortuitous event and unpredictability'. https://www.juridice.ro/678702/pandemia-covid-19-intre-forta-ma jora-caz-fortuit-si-impreviziune.html. 
Pop, L., Popa I.F. \& S.I. Vidu (2012). 'Elementary civil law treaty. Obligations under the new Civil Code'. Bucharest: Judicial Universe Press (Tratat elementar de drept civil. Obligațiile conform noului Cod civil).

Strambei, M. (2020). 'Public procurement - dynamics and perspectives in the current context generated by the COVID pandemic - 19' in Public Procurement Journal (Achizitiile publice - dinamica şi perspective în contextul actual generat de pandemia de COVID - 19) 151:11-14.

Sandar, V. (2013). 'The configuration of unpredictabiliy in the new Civil Code. Considerations on hardship clauses', in Romanian Journal of Business Law 10:61-77.

Togan, R. (2017). 'Analiza teoriei impreviziunii în cadrul juridic actual' (Analysis of the theory of unpredictability in the current legal framework)', https://abcjuridic.ro/anali za-teoriei-impreviziunii-in-cadrul-juridic-actual/\#_ftn12

Ungureanu, C.T. (2015). "Impreviziunea în contractele de comerț international' (Unpredictabiliy in international trade contracts) in Journal of Legal Sciences, http:// drept.ucv.ro/RSJ/images/articole/2015/RSJ_no. 1_2015.pdf.

Seperiusi-Vlad, A. (2020). 'The theory of unpredictability in the field of inventions', in Law Journal (Teoria impreviziunii în domeniul invențiilor) 3:49-77.

Sieulean, C. (2020), 'What happens to commercial contracts in the current context? Force majeure may be invoked to suspend obligations or not?' https://www.universuljuri dic.ro/ce-se-intampla-cu-contractele-comerciale-in-contextul-actual-poate-fi-invoca ta-forta-majora-pentru-suspendarea-obligatiilor-sau-nu/.

Zamşa, C.E. (2006). Teoria impreviziunii. Studiu de doctrină și jurisprudență (The theory of unpredictability. Study of doctrine and jurisprudence). Bucharest: Hamangiu Press.

Zimmermann, R. (2002). 'Remedies for Non-Performance: The Revised German Law of Obligations Viewed against the Background of the Principles of European Contract Law'. Edinburgh: Backhaus. 
